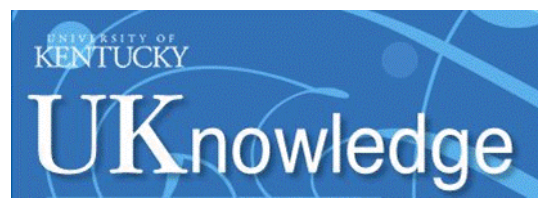

University of Kentucky

UKnowledge

8-6-2018

\title{
Quantifying Plant Soluble Protein and Digestible Carbohydrate Content, Using Corn (Zea mays) as an Exemplar
}

\author{
Carrie A. Deans \\ Texas A \& M University \\ Gregory A. Sword \\ Texas A \& M University \\ Paul A. Lenhart \\ University of Kentucky, palenhart@uky.edu \\ Eric Burkness \\ University of Minnesota \\ William D. Hutchison \\ University of Minnesota
}

See next page for additional authors

Follow this and additional works at: https://uknowledge.uky.edu/entomology_facpub

Part of the Entomology Commons, Plant Sciences Commons, and the Soil Science Commons

Right click to open a feedback form in a new tab to let us know how this document benefits you.

\section{Repository Citation}

Deans, Carrie A.; Sword, Gregory A.; Lenhart, Paul A.; Burkness, Eric; Hutchison, William D.; and Behmer, Spencer T., "Quantifying Plant Soluble Protein and Digestible Carbohydrate Content, Using Corn (Zea mays) as an Exemplar" (2018). Entomology Faculty Publications. 169.

https://uknowledge.uky.edu/entomology_facpub/169

This Article is brought to you for free and open access by the Entomology at UKnowledge. It has been accepted for inclusion in Entomology Faculty Publications by an authorized administrator of UKnowledge. For more information, please contact UKnowledge@lsv.uky.edu. 


\section{Quantifying Plant Soluble Protein and Digestible Carbohydrate Content, Using Corn (Zea mays) as an Exemplar}

\section{Digital Object Identifier (DOI)}

https://doi.org/10.3791/58164

\section{Notes/Citation Information}

Published in Journal of Visualized Experiments, issue 138, e58164, p. 1-11.

Copyright $@ 2018$ Journal of Visualized Experiments

The copyright holder has granted the permission for posting the article here.

\section{Authors}

Carrie A. Deans, Gregory A. Sword, Paul A. Lenhart, Eric Burkness, William D. Hutchison, and Spencer T. Behmer 


\title{
Video Article \\ Quantifying Plant Soluble Protein and Digestible Carbohydrate Content, Using Corn (Zea mays) As an Exemplar
}

\author{
Carrie A. Deans ${ }^{1,2}$, Gregory A. Sword ${ }^{1}$, Paul A. Lenhart ${ }^{3}$, Eric Burkness ${ }^{2}$, William D. Hutchison ${ }^{2}$, Spencer T. Behmer ${ }^{1}$ \\ ${ }^{1}$ Department of Entomology, Texas A\&M University \\ ${ }^{2}$ Department of Entomology, University of Minnesota \\ ${ }^{3}$ Department of Entomology, University of Kentucky
}

Correspondence to: Carrie A. Deans at cadeans@tamu.edu

URL: https://www.jove.com/video/58164

DOI: doi:10.3791/58164

Keywords: Environmental Sciences, Issue 138, Macronutrients, nutrition, herbivory, agriculture, geometric framework, insect, physiology

Date Published: 8/6/2018

Citation: Deans, C.A., Sword, G.A., Lenhart, P.A., Burkness, E., Hutchison, W.D., Behmer, S.T. Quantifying Plant Soluble Protein and Digestible Carbohydrate Content, Using Corn (Zea mays) As an Exemplar. J. Vis. Exp. (138), e58164, doi:10.3791/58164 (2018).

\section{Abstract}

Elemental data are commonly used to infer plant quality as a resource to herbivores. However, the ubiquity of carbon in biomolecules, the presence of nitrogen-containing plant defensive compounds, and variation in species-specific correlations between nitrogen and plant protein content all limit the accuracy of these inferences. Additionally, research focused on plant and/or herbivore physiology require a level of accuracy that is not achieved using generalized correlations. The methods presented here offer researchers a clear and rapid protocol for directly measuring plant soluble proteins and digestible carbohydrates, the two plant macronutrients most closely tied to animal physiological performance. The protocols combine well characterized colorimetric assays with optimized plant-specific digestion steps to provide precise and reproducible results. Our analyses of different sweet corn tissues show that these assays have the sensitivity to detect variation in plant soluble protein and digestible carbohydrate content across multiple spatial scales. These include between-plant differences across growing regions and plant species or varieties, as well as within-plant differences in tissue type and even positional differences within the same tissue. Combining soluble protein and digestible carbohydrate content with elemental data also has the potential to provide new opportunities in plant biology to connect plant mineral nutrition with plant physiological processes. These analyses also help generate the soluble protein and digestible carbohydrate data needed to study nutritional ecology, plant-herbivore interactions and food-web dynamics, which will in turn enhance physiology and ecological research.

\section{Video Link}

The video component of this article can be found at https://www.jove.com/video/58164/

\section{Introduction}

Plant biomass forms the foundation of virtually all terrestrial food-webs. Plants acquire nutritional elements from the soil through their roots systems and utilize sunlight in their foliar tissues to synthesize biomolecules. In particular, carbon and nitrogen are used to create carbohydrates, proteins (comprised of amino acids), and lipids that are needed to build plant biomass (it should be noted that in plant physiology the term "macronutrient" often refers to soil elements, such as N, P, K, and S, however, throughout this paper this term will refer to biomolecules, such as proteins, carbohydrates, and lipids). When herbivores consume plant material, the macronutrients contained in plant tissues are broken down into their constituent parts and then used to drive the physiological processes of the consumer. In this way, plant macronutrients have a strong influence on consumer physiology along with important implications for higher order ecological interactions and food-web dynamics.

Across the animal kingdom, soluble protein and digestible carbohydrates are the macronutrients most closely tied to survival, reproduction, and performance ${ }^{1}$. Moreover, the majority of animals actively regulate their intake of these two macronutrients to meet their physiological demands ${ }^{1,2}$. This is particularly true for insect herbivores that detect the concentrations of sugars and amino acids in plant tissues, which in turn directs feeding behavior. As a result, plant soluble protein and digestible carbohydrate content has played a strong role in the evolution of plant-insect interactions.

While data on plant soluble protein and digestible carbohydrate content are relatively rare (but see $e^{6,7,8,9,10,11}$ ), there is a preponderance of data available on plant elemental content (carbon, nitrogen, and phosphorus). Largely this is because elements play a primary role in plant mineral nutrition ${ }^{3,4,5}$. Where elements are measured, correlations have been used to extrapolate the amount of soluble protein and digestible carbohydrate, but accurate calculations are often difficult to obtain. For instance, it is impossible to use carbon as an indicator of plant digestible carbohydrate content because carbon is ubiquitously present in all organic compounds. A stronger relationship exists between elemental nitrogen and plant soluble protein content, and generalized nitrogen-to-protein conversion factors are often utilized. However, there is strong evidence that nitrogen-to-protein conversions are highly species-specific ${ }^{12,13,14,15}$, making the use of generalized conversion likely inaccurate. Because of this, nitrogen-to-protein conversion factors often lack precision, particularly to the extent that is required for nutritional studies on 
herbivores. Also, the presence of $\mathrm{N}$-containing plant allelochemicals, such as alkaloids and glucosinolates that are often toxic to herbivores, can confound these conversions.

Here, we offer two chemical assays for measuring the concentration of soluble proteins and digestible carbohydrates in plant tissues. These assays are presented separately, but it is suggested that they be used concurrently to analyze the same plant samples in order to achieve a more comprehensive analysis of plant macronutrients. Both employ similar methodologies, consisting of an extraction step, followed by quantification via absorbance. Plant sample prep is also identical for both protocols, making it easy to run both analyses in tandem. The utility of these assays do not stem from their novelty, as they rely on older, (Bradford, Jones, Dubois) well-established colorimetric assays ${ }^{16,17,18}$, but here we have organized a clear and easy-to-follow protocol that combines these methods with more obscure plant-specific extraction techniques ${ }^{17,19}$ in order to make the application of these assays more accessible to those in plant-relevant fields.

For both assays, plant macronutrients are first extracted physically by freezing, lyophilizing, and grinding the plant material. For the soluble protein assay, further chemical extraction is done ${ }^{17,19}$ through several rounds of vortexing and heating samples in $\mathrm{NaOH}$ solution. The wellknown Bradford assay, utilizing Coomassie brilliant blue G-250, is then used to quantify soluble proteins and polypeptides between 3,000-5,000 Daltons ${ }^{16,17}$. This assay has a detection range between $1-20 \mu \mathrm{g}$ total proteins per microplate well or $<25 \mu \mathrm{g} / \mathrm{mL}$, but does not measure free amino acids. The extraction step of the digestible carbohydrate assay is based on the dilute acid method of Smith et al. ${ }^{20}$ and allows for the isolation of soluble sugars, starch, and fructosan - but not structural carbohydrates. A phenol-sulfuric acid quantification method is taken from Dubois et al. $^{18}$ and measures all mono-, oligo-, and polysaccharides (as well as methyl derivatives). This assay is able to quantify specific sugars, but here we use it as an indicator of total digestible carbohydrate content (see Smith et al. ${ }^{20}$ for more detailed analysis). Together, these assays measure the two macronutrients that are strongly tied to plant eco-physiology and herbivore performance, providing important data on resource quality at the base of terrestrial food-webs. Presenting these protocols promotes the generation of plant macronutrient datasets in order to obtain a more thorough understanding of plant physiology, herbivore nutritional ecology, and plant-herbivore interactions.

\section{Plant Collection and Processing}

1. Collect and process plant samples

1. After collecting plant samples, flash-freeze samples by dipping plant material into liquid nitrogen with forceps and store at $-80^{\circ} \mathrm{C}$. If the plant samples collected are too large to flash-freeze, quickly cool the samples using dry ice and transfer to a $-80^{\circ} \mathrm{C}$ freezer as soon as possible. The macronutrient content of plant material can change after tissues are separated from the plant, so it is important to freeze plant samples as soon as possible after collection.

CAUTION: Liquid nitrogen can cause severe frostbite when in contact with skin. Please make sure to transport liquid nitrogen in approved containers and wear proper PPE during its handling, including cryo-gloves, eye googles, face shield, apron, and a lab coat.

2. Lyophilize plant material using a freeze-dryer to ensure that the tissues are metabolically inactive while water is being removed. Dry until the mass of the sample stabilizes to ensure all water has been removed.

3. Once samples are dry, grind into a fine powder using a grinder or mill. Store samples in a desiccating cabinet until analysis.

\section{Soluble Protein Assay}

1. Sample Preparation

1. Weigh out replicate samples of each tissue, approximately $20 \mathrm{mg}$ each, into $1.5 \mathrm{~mL}$ polystyrene microcentrifuge tubes and label tubes. These samples will subsequently be referred to as unknown samples. Record the exact mass of each sample, as this information will be required to calculate the \%soluble protein in each unknown sample. Use microcentrifuge tubes with locking lids, as non-locking lids may open during the subsequent heating step, resulting in loss of sample solution.

2. Solubilize and isolate unknown sample proteins

1. Using a micro-pipettor, add $500 \mu \mathrm{L}$ of $0.1 \mathrm{M} \mathrm{NaOH}$ to each tube. Close lids tightly and sonicate for 30 minutes. Preheat a hot water bath $90^{\circ} \mathrm{C}$.

CAUTION: Sodium hydroxide is a strong base and can cause burns when in contact with skin. Although $0.1 \mathrm{M} \mathrm{NaOH}$ represents a low concentration, wear protective gloves to avoid skin irritation.

2. Place tubes in a rack in the hot water bath for 15 minutes.

3. Centrifuge tubes at $15,000 \times \mathrm{g}$ for 10 minutes. Pipette the supernatant liquid into new labeled microcentrifuge tubes, using a new pipette tip for each sample. Add $300 \mu \mathrm{L}$ of $0.1 \mathrm{M} \mathrm{NaOH}$ to the tube containing the pellet and centrifuge again at $15,000 \times \mathrm{g}$ for 10 minutes. Again, collect the supernatant liquid and combine it with the other supernatant fluid from the same sample. This is a potential stopping point, and samples can be stored at $4{ }^{\circ} \mathrm{C}$ overnight if needed.

3. Precipitate plant proteins

1. Neutralize the $\mathrm{pH}$ of the supernatant solution by adding $11 \mu \mathrm{L}$ of $5.8 \mathrm{M} \mathrm{HCl}$. Confirm a $\mathrm{pH}$ of $\sim 7$ by dipping litmus paper into each sample solution

CAUTION: Hydrochloric acid is a strong corrosive acid that can cause burns when in contact with skin (skin application or inhalation). Please wear gloves to prevent skin irritation while handling $\mathrm{HCl}$.

2. Add $90 \mu \mathrm{L}$ of $100 \%$ trichloroacetic acid (TCA) to each tube and incubate tubes on ice for 30 minutes. The precipitation of proteins will turn the solution from clear to opaque. If this does not occur after 30 minutes, refrigerate the tubes for 1 hour. This is a potential stopping point, and samples can be stored at $4{ }^{\circ} \mathrm{C}$ overnight if needed.

CAUTION: Trichloroacetic acid is corrosive. Please wear gloves when handling to prevent contact with skin and avoid inhalation. 
3. Centrifuge samples at $13,000 \times \mathrm{g}$ for 10 minutes at $4{ }^{\circ} \mathrm{C}$. Carefully remove TCA supernatant by suctioning it out using a vacuum line attached to a fine glass micropipette tip (the same tip can be used across samples). Do not disturb the protein pellet by avoiding heavy suction and keeping an appropriate distance between pipette tip and the pellet.

4. Wash pellet quickly with $100 \mu \mathrm{L}$ of $-20^{\circ} \mathrm{C}$ acetone. This step removes any remaining TCA from the pellet, which can interfere with the subsequent Bradford assay; however, acetone will start to dissolve the protein pellet if left in contact too long, so acetone should be added then quickly extracted from the pellet within 5 seconds.

5. Allow acetone to evaporate by placing tubes in a fume hood or refrigerator. Then, dissolve the protein pellet by adding $1 \mathrm{~mL}$ of $0.1 \mathrm{M}$ $\mathrm{NaOH}$ to each tube. Fully dissolving the pellet may require several rounds of heating in a hot water bath, vortexing, and sonicating. Note: The longer the tubes sit in the fume hood or refrigerator and the drier the pellets get, the more difficult they will be to re-solubilize. It is suggested to dry the pellet for 30 minutes, and then check for the presence of acetone every 10-15 minutes until it is clear that the acetone has evaporated (no acetone fumes are detectable)

4. Mix standard solutions, dilute unknown sample solutions, and quantify the total protein content of unknown samples using the Bradford assay

1. Prepare bovine immunoglobulin $\mathrm{G}(\mathrm{IgG})$ standard solutions according to the concentrations listed in Table $\mathbf{1}$ (lyophilized or lgG stock solution can be mixed with deionized water to achieve each concentration). Store standards at $4{ }^{\circ} \mathrm{C}$. In a 96 -well plate, add $160 \mu \mathrm{L}$ of each IgG standard solution in triplicate starting at the $A 1$ position of the well plate $(0 \mu \mathrm{g} / \mu \mathrm{L}$ in $\mathrm{A} 1, \mathrm{~A} 2, \mathrm{~A} 3 \mathrm{position}, 0.0125 \mu \mathrm{g} / \mu \mathrm{L}$ in $\mathrm{B} 1$, B2, B3 positions, etc.).

2. Prepare a diluted $\mathrm{NaOH}$ solution by adding $50 \mu \mathrm{L}$ of $0.1 \mathrm{M} \mathrm{NaOH}$ to $950 \mu \mathrm{L}$ of distilled water. As a blank negative control, add $60 \mu \mathrm{L}$ of this solution to the well plate in triplicate (G1, G2, G3 positions).

3. Prepare dilutions of unknown samples by adding $50 \mu \mathrm{L}$ of each sample solution to $950 \mu \mathrm{L}$ of distilled water in a new $1.5 \mathrm{~mL}$ microcentrifuge tube. Then, add $60 \mu \mathrm{L}$ of each diluted sample to the well plate in triplicate, starting at the $\mathrm{H} 1$ position. A 96-well plate should allow for the analysis of 6 standards, 1 blank, and 25 unknown samples when read in triplicate. Each well plate analyzed should contain its own IgG standard and blank samples.

4. Add $100 \mu \mathrm{L}$ of distilled water to all blank and unknown samples wells. Now each well should contain a total of $160 \mu \mathrm{L}$. Using a multichannel pipette ( 8 channels), add $40 \mu \mathrm{L}$ of Coomassie brilliant blue G-250 protein dye to every well in the first column of the well plate. Mix the dye with the samples by plunging several times. Repeat for all other columns, replacing pipette tips to avoid contamination. CAUTION: Coomassie brilliant blue G-250 is an irritant and contact with skin, eyes, or lungs should be avoided. Please wear gloves to prevent contact with skin. If contact with skin occurs, this product will stain.

5. Use a needle to pop any bubbles present in the wells, as they may interfere with the microplate spectrophotometer reading. Clean the needle to avoid contamination between wells. Let the microplate incubate at room temperature for 5 minutes.

6. Using a microplate spectrophotometer, record the absorbance values for each well at $595 \mathrm{~nm}$.

7. Record the average absorbance for the three blank wells and subtract this value from each of the standard and unknown sample readings. Then, record the average absorbance for each standard and unknown sample.

Note: To calculate the amount of protein present in each unknown sample using the standard curve, it is easiest to regress the average absorbance of each standard against the micrograms of protein present in each standard, but one can plot the protein concentration $(\mu \mathrm{g} / \mu \mathrm{L})$ of each standard if desirable. The following calculations, however, refer to a standard curve based on micrograms, not concentrations $(\mu \mathrm{g} / \mu \mathrm{L})$

8. Plot the average absorbance of each standard against the total amount of protein present in each standard well (Table 1). Fit a linear regression line to these data and use the equation to calculate the amount of protein $(\mu \mathrm{g})$ in each unknown sample well based on the average absorbance (Figure 1a).

Note: The correlation coefficient ( $r$ value) of this line should be greater than 0.98 and routinely near 0.99 . The standard regression will be specific to each plate, hence the unknown sample wells in each plate must be analyzed separately.

9. Once the average amount of protein is calculated for each unknown sample well, use the following equation to calculate the total amount of protein $(\mu \mathrm{g})$ in each original sample:

$M_{p}=\left(\left(\left(W_{p} / 60\right) \times 1000\right) / 50\right)^{*} 1000$

$\mathrm{M}_{\mathrm{p}}=\mu \mathrm{g}$ of protein in original sample

$\mathrm{W}_{\mathrm{p}}=\mu \mathrm{g}$ of protein in unknown sample well

1. Then, use the following equation to determine the percentage of protein in each sample:

$\mathrm{P}_{\mathrm{p}}=\left(\left(\mathrm{M}_{\mathrm{p}} / 1000\right) / \mathrm{M}_{\mathrm{i}}\right)^{* 100}$

$P_{p}=\%$ protein in sample

$M_{\mathrm{i}}=$ initial mass of sample $(\mathrm{mg})$

Note: In some cases, the sample may surpass the upper absorbance threshold. If so, sample solutions may require further dilution at step 2.4.3.

Additional dilutions must then be accounted for in subsequent calculations. Some microplate reader brands also provide computer software that will automatically calculate the average protein concentration of each unknown sample based on the standard curve data.

\section{Digestible Carbohydrate Assay}

\section{Sample Preparation}

1. Weigh out replicate samples of each tissue, approximately $20 \mathrm{mg}$ each, into glass $15 \mathrm{~mL}$ tubes with rubber-lined screw caps (100 mm length). These sample will subsequently be referred to as unknown samples. Label tubes with a waterproof marker or with labelling tape on the lids and record the exact mass of each sample, as this information will be required to calculate the \%carbohydrates in each unknown sample.

2. Extract digestible carbohydrates from each unknown sample.

1. Add $1 \mathrm{~mL}$ of $0.1 \mathrm{M} \mathrm{H}_{2} \mathrm{SO}_{4}$ to each tube and screw caps onto tubes tightly. Place in a boiling water bath for 1 hour. 
CAUTION: Sulfuric acid is very corrosive. Please wear gloves, eye googles, and an apron when handling $\mathrm{H}_{2} \mathrm{SO}_{4}$ and perform this step in a fume hood.

2. Cool off tubes in a tepid water bath. Pour tube contents into labeled $1.5 \mathrm{~mL}$ microcentrifuge tubes (do not be concerned if some plant material remains in the glass tubes).

3. Centrifuge tubes at $15,000 \times \mathrm{g}$ for 10 minutes. Remove the supernatant liquid with a micro-pipettor and place into new labeled $1.5 \mathrm{~mL}$ microcentrifuge tubes. Tubes can be refrigerated overnight at this point. If continuing with assay, refer to step 3.3.2.

3. Mix standard solutions and quantify the total digestible carbohydrate content of unknown samples.

1. Prepare $\mathrm{D}(+)$ glucose standard solutions with the concentrations listed in Table 2. Prepare six glass test tubes with $400 \mu \mathrm{L}$ of each standard solution.

2. Pipette $15 \mu \mathrm{L}$ of each unknown sample into its own test tube and add $385 \mu \mathrm{L}$ of distilled water to each for a total volume of $400 \mu \mathrm{L}$ in each test tube. In a fume hood, add $400 \mu \mathrm{L}$ of $5 \%$ phenol to each standard and unknown sample test tube, and then quickly pipette 2 $\mathrm{mL}$ of concentrated $\mathrm{H}_{2} \mathrm{SO}_{4}$ into each tube. Do not touch the test tube contents with the pipette tip, just add to the solution surface (a repeater pipette works best for this).

3. Let tubes incubate for 10 minutes, and then carefully vortex the tubes to mix contents. Incubate for an additional 30 minutes. CAUTION: Phenol and sulfuric acid are corrosive irritants. To protect from exposure to skin, eyes, and inhalation, this step should be performed in a chemical fume hood using the proper PPE, which includes: face shield or eye goggles, rubber gloves, lab apron, and boots. Mixing phenol with sulfuric acid also results in an exothermic reaction, which will result in the tubes becoming hot.

4. Pipette $800 \mu \mathrm{L}$ of sample from each tube into each of 3 polystyrene $1.5 \mathrm{~mL}$ semi-micro cuvettes ( 3 technical replicates per sample). Set the spectrophotometer to read at $490 \mathrm{~nm}$. Calibrate to a blank cuvette containing distilled water before reading standards or unknown samples, and intermittently throughout sample readings. Run each cuvette through a spectrophotometer and record the absorbance. Average across technical replicates for each unknown sample.

Note: In some cases, samples may surpass the upper absorbance threshold. If so, samples should be diluted at step 3.2.3. Dilutions must also be accounted for in subsequent calculations.

5. Calculate the average absorbance for each standard.

Note: To calculate the amount of total digestible carbohydrates present in each unknown sample using the standard curve, it is easiest to regress the average absorbance of each standard against the micrograms of $D(+)$ glucose present in each standard, but one can also plot the $\mathrm{D}(+)$ glucose concentration $(\mu \mathrm{g} / \mu \mathrm{L})$ of each standard if desirable. The following calculations, however, refer to a standard curve based on micrograms, not concentrations $(\mu \mathrm{g} / \mu \mathrm{L})$.

6. Calculate the standard curve by plotting the average absorbance against the total amount of $D(+)$ glucose $(\mu \mathrm{g})$ in each standard solution. Fit a linear regression line to these data, and then use the following equation to calculate the total amount of carbohydrates $(\mu \mathrm{g})$ in each unknown sample:

$M_{c}=\left(\left(\left(A_{x}-b\right) / m\right) /(15)\right)^{*} 1000$

$M_{c}=\mu g$ of carbohydrates in sample

$A_{x}=$ average absorbance of unknown sample

$\mathrm{b}=\mathrm{y}$-intercept (standard regression line)

$\mathrm{m}=$ slope (standard regression line)

The correlation coefficient of this line should be greater than 0.98 and routinely near 0.99 . Then, use the following equation to determine the percentage of carbohydrates in each sample:

$P_{c}=\left(\left(M_{d} / 1000\right) /\left(M_{i}\right)\right)^{*} 100$

$P_{c}=\%$ carbohydrates

$\mathrm{M}_{\mathrm{i}}=$ initial mass of sample $(\mathrm{mg})$

\section{Representative Results}

To show the usefulness of these methods, we analyzed the soluble protein and digestible carbohydrate content of four different field and sweetcorn tissues that serve as distinct potential nutritional resources for insect herbivores. We collected ears of corn from three agricultural regions in the United States (Minnesota, North Carolina, and Texas), encompassing five different varieties of sweet corn (i.e., genotypes) and one variety of field corn as an outgroup. Table 3 shows a summary of these corn samples and where they were collected. All varieties were collected at maturity, but due to developmental differences between varieties, they were not all collected at the same day after planting. We processed the ears into distinct tissues by quickly separating the husks (modified leaves surround the cob), and silks (shiny fibers between the husk and kernels) from the ear before storing all tissues at $-80^{\circ} \mathrm{C}$ as indicated in the Methods. Each tissue was then freeze-dried. Once dried, we separated the kernels from the base and tip of the ear by shaving off kernels from the top one-third (tip) and bottom one-third (base) of the cob. Next, all tissues were ground into a fine powder. We then analyzed husk, silk, tip kernel, and base kernel tissue samples for soluble protein and digestible carbohydrate content according to the procedures outlined in the Methods above. Given constraints on the amount of tissue available, we analyzed a total of 217 plant samples for both soluble protein and digestible carbohydrate content.

Soluble Protein

We ran nine sample plates through the spectrophotometer in total, and overall, standard curves had high correlation coefficients $(r)$, with values between $0.985-1.00$. Figure 1 shows the standard curve obtained with the highest $(A)$ and lowest $(B) r$ values to exhibit the variability we observed across plates. We calculated the \%soluble protein for all samples using initial sample mass (Table 4) and then analyzed the data for statistical differences in soluble protein content between regions, varieties, and tissue types. Data were rank-transformed to meet normality assumptions when necessary. 
We observed significant differences in soluble protein content between regions (Welch ANOVA; $F_{(2,133.5)}=4.303, P=0.015$ ), as a result, data from each region were subsequently analyzed separately. Minnesota samples showed a significant interaction between variety and tissue type on soluble protein content (two-way ANOVA; $F_{(3,64)}=16.51, P<0.001$ ). Most tissues had similar soluble protein content in both varieties, except for base kernels, where the sweet corn variety contained almost 7 times the amount compared to the field corn variety. For the field corn variety (Syngenta/NK-3122A-EZ), husks and silks were similar and had the lowest soluble protein content of all tissues. Kernels from the tip of the ear had the highest soluble protein content, and kernels from the base of the ear were intermediate (Figure 2a). For the sweet corn variety (Providence Bicolor), all tissues were distinct, with the husks and silks containing the lowest soluble protein content, and base kernels contained $\sim 2.5$ times more than tip kernels (Figure $\mathbf{2 b}$ ).

North Carolina samples also showed a significant interaction between variety and tissue type (two-way ANOVA; $\left.F_{(3,77)}=3.33, P<0.024\right)$. Most tissues showed similar soluble protein content across varieties, except for tip kernels which exhibited a higher content in non-Bt variety (Sweet G90 Hybrid). For the Bt variety (Seedway Bt 1576) husks were the tissue with the lowest soluble protein content, followed by silks and tip kernels, which had a similar content. Base kernels had the highest soluble protein content but were not statistically different from that of tip kernels (Figure 2C). In the non-Bt variety (Sweet G90 Hybrid), all tissues were distinct except for tip and base kernels which were statistically similar. Husks had the lowest soluble protein content, followed by silks, and tip and base kernels which had the highest content (Figure 2d).

Texas samples showed significant differences in soluble protein content between varieties (two-way ANOVA; $F_{(1,76)}=12.91, P=0.001$ ) and tissues (two-way ANOVA; $F_{(3,76)}=21.90, P<0.001$ ), but no significant interaction (two-way ANOVA; $F_{(3,76)}=0.436, P=0.728$ ). Overall, the bicolor variety (Sh2 SS2742 NAT III) showed a lower average soluble protein content than the Silver Queen variety (TRTD F1 (su)). Across both varieties, husks had the lowest protein content, followed by silks, and then tip and base kernels, both of which had similarly high content (Figure 2e-f).

Digestible Carbohydrates

Because all samples were analyzed at one time, we only ran one standard curve. Figure 1c shows that the correlation coefficient was high, at 0.998 . We calculated the \%digestible carbohydrate content for all samples (Table 5) and then analyzed data for statistical differences in digestible carbohydrate content between regions, varieties, and tissue types. Data were rank-transformed when necessary to meet normality assumptions

There were no significant differences in between regions (ANOVA; $F_{(2,216)}=1.47, P=0.231$ ), but for the sake of continuity with the protein analyses we again analyzed data from each region separately. Minnesota samples showed no significant differences in digestible carbohydrate content between varieties (two-way ANOVA; $F_{(1,64)}=0.00014, P=0.990$ ) or tissue type (two-way ANOVA; $F_{(3,64)}=0.818, P=0.489$ ). There was also no significant interaction between variety and tissue (two-way ANOVA; $F_{(3,64)}=2.26, P=0.092$ ). Figure $2 a-b$ shows that all tissues exhibited an average content of $36.5 \%( \pm 0.53)$.

North Carolina samples showed a significant effect of tissue type on digestible carbohydrate content (two-way ANOVA; $\left.F_{(3.77)}=3.99, P=0.011\right)$, but no effect of variety (two-way ANOVA; $F_{(1,77)}=1.06, P=0.307$ ) or interaction (two-way ANOVA; $F_{(3,77)}=0.465, P=0.708$ ). Figure $2 \mathrm{c}$-d shows that silks had the lowest digestible carbohydrate content, followed by husks, tip kernels, and base kernels. All tissues were statistically similar except for silks and base kernels.

Texas samples showed no significant effect of variety (two-way ANOVA; $F_{(1,76)}=0.834, P=0.364$ ) or tissue type (two-way ANOVA; $F_{(3,76)}=1.03$, $P=0.385$ ), but did show a significant interaction (two-way ANOVA; $F_{(3,76)}=3.34, P=0.024$ ). This effect was largely because base kernels in the bicolor variety (Sh2 SS2742 NAT III) had a significantly higher digestible carbohydrate content than those in the Silver Queen variety (TRTD F1 (su)). Figure 2e-f shows that there were no statistical differences in digestible carbohydrate content across tissue types in the Silver Queen variety (TRTD F1 (su)), but there was a significant difference between silk and base kernel tissues for the bicolor variety (Sh2 SS2742 NAT III) 
A).

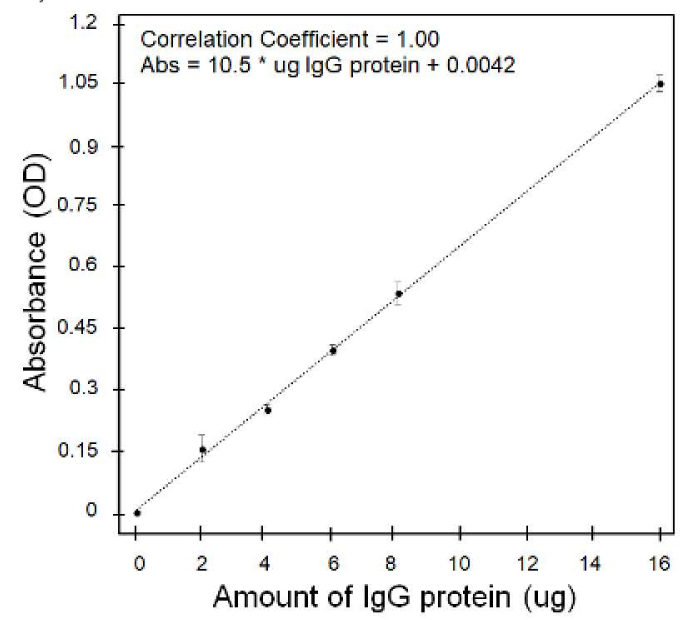

B).

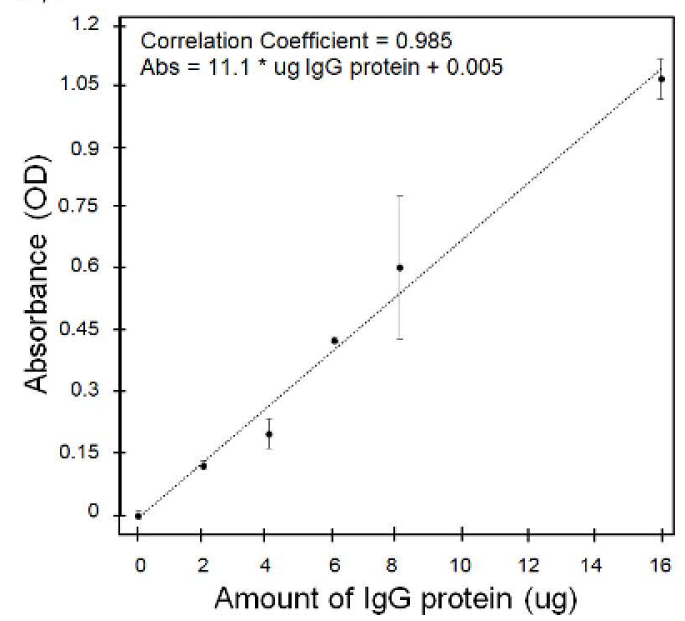

C).

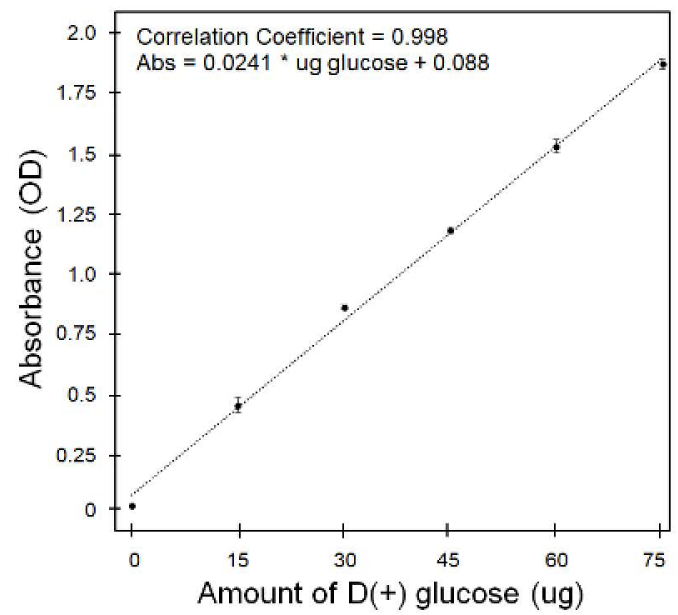

Figure 1. Standard curves for macronutrient assays. (A) The standard curve for the soluble protein assay showing the plate with the highest correlation coefficient (best curve). (B) The standard curve for the soluble protein assay showing the plate with the lowest correlation coefficient (worst curve). (C) The standard curve for the digestible carbohydrate assay. Please click here to view a larger version of this figure. 
A).

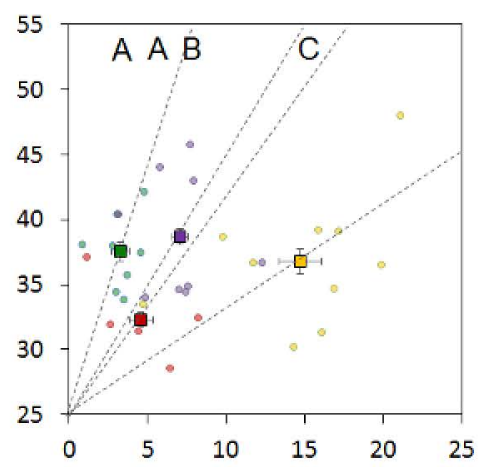

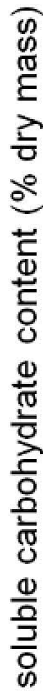

C).

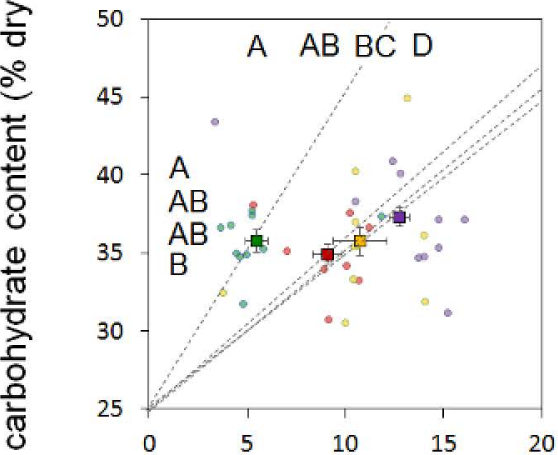

E).

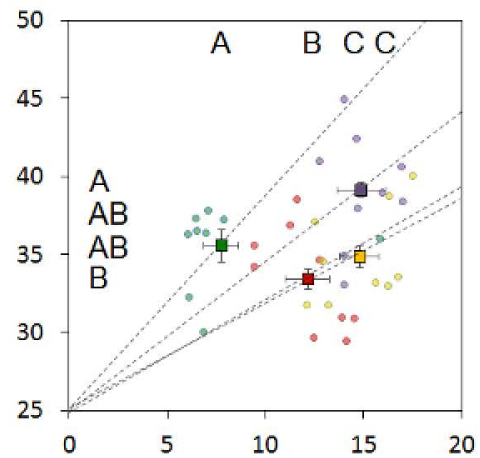

B).

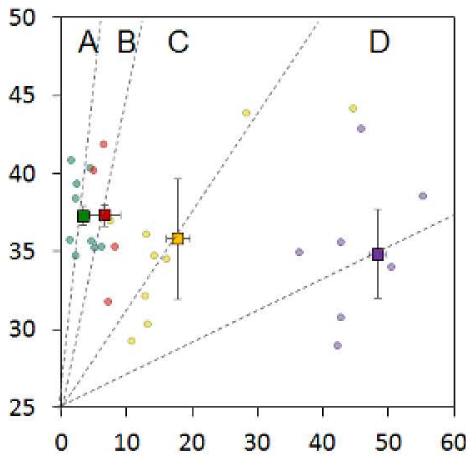

D).

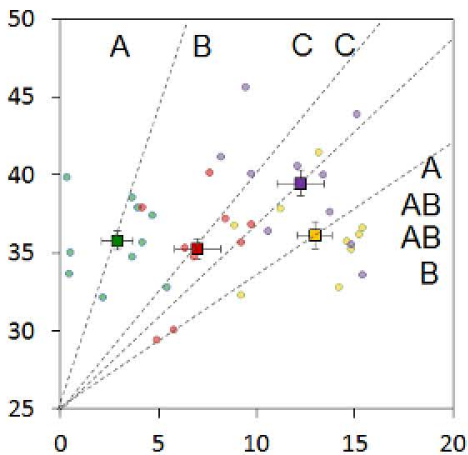

F).

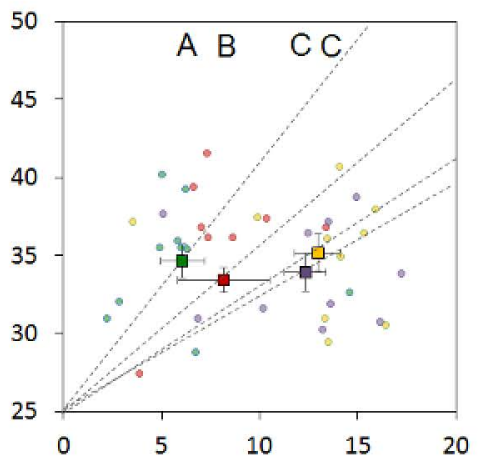

soluble protein content ( $\%$ dry mass)

Figure 2. Mean \%soluble protein and \%digestible carbohydrate content for each tissue type. (A) MN-Bt Syngenta/NK-3122A-EZ (field corn), (B) MN- non-Bt Providence Bicolor, (C) NC- Seedway Bt 1576, (D) NC- non-Bt Sweet G90 Hybrid, (E) TX- Sh2 SS2742 F1 NAT III Bicolor, (F) TX- Silver Queen TRTD F1 (su). Circles show raw data, while squares show the mean values. Green (husk), red (silk), yellow (tip kernels), and purple (base kernels). The dotted-lines connecting the origin to each square show the $P: C$ ratio for each tissue (ratio is the slope of the dotted-line). Letters show post hoc results for protein differences along the top and carbohydrate differences along the side, with different letters representing significantly different values across tissues. Please click here to view a larger version of this figure. 


\begin{tabular}{|l|l|}
\hline IgG Concentration (ug/uL) & Protein in Standard Samples (ug) \\
\hline 0.0000 & 0 \\
\hline 0.0125 & 2 \\
\hline 0.0250 & 4 \\
\hline 0.0375 & 6 \\
\hline 0.0500 & 8 \\
\hline 0.1000 & 16 \\
\hline
\end{tabular}

Table 1.Standard curve calculations for the soluble protein assay. The amount of protein in each standard is calculated by taking the concentration of each standard and multiplying it by the amount of standard solution in each well $(160 \mu \mathrm{L})$.

\begin{tabular}{|l|l|}
\hline$D(+)$ glucose Concentration (ug/uL) & D(+)glucose in Standard Samples (ug) \\
\hline 0.0000 & 0 \\
\hline 0.0375 & 15 \\
\hline 0.0750 & 30 \\
\hline 0.1125 & 45 \\
\hline 0.1500 & 60 \\
\hline 0.1875 & 75 \\
\hline
\end{tabular}

Table 2. Standard curve calculation for digestible carbohydrate assay. The amount of glucose in each standard is calculated by taking the concentration of each standard and multiplying it by the amount of standard solution in each test tube $(400 \mu \mathrm{L})$.

\begin{tabular}{|l|l|l|l|}
\hline Region & Variety & Location & N \\
\hline Minnesota & $\begin{array}{l}\text { Bt Syngenta/NK-3122A-EZ (field } \\
\text { corn) }\end{array}$ & $\begin{array}{l}\text { Rosemount, MN (44.7070, } \\
-93.1073)\end{array}$ & 10 \\
\cline { 2 - 4 } & non-Bt Providence Bicolor & $\begin{array}{l}\text { Rosemount, MN (44.7070, } \\
-93.1073)\end{array}$ & 10 \\
\hline \multirow{2}{*}{ North Carolina } & non-Bt Sweet G90 Hybrid & $\begin{array}{l}\text { Rocky Mount, NC (35.8918, } \\
-77.6780)\end{array}$ & 10 \\
\cline { 2 - 5 } & Seedway Bt 1576 & Edenton, NC (36.1758, -76.7057) & 10 \\
\hline Texas & Sh2 SS2742 F1 NAT III Bicolor & Lubbock, TX (33.6935, -101.8249) & 10 \\
\cline { 2 - 5 } & Silver Queen TRTD F1 (su) & Lubbock, TX (33.6935, -101.8249) & 10 \\
\hline
\end{tabular}

Table 3. Summary of the corn sampling location and varieties. For each region and variety combination, 10 ears were collected and four tissues were analyzed: husk, silks, tip kernels, and base kernels.

\begin{tabular}{|l|l|l|l|l|l|}
\hline \multirow{2}{*}{ Region } & Variety & \multicolumn{2}{|l|}{ \% soluble protein } & silks & tip kernel \\
\cline { 2 - 6 } & & husk & $4.57 \pm 1.27$ & $14.74 \pm 1.54$ & base kernel \\
\hline Minnesota & $\begin{array}{l}\text { Bt Syngenta/ } \\
\text { NK-3122A-EZ (field } \\
\text { corn) }\end{array}$ & $3.29 \pm 0.38$ & $6.71 \pm 0.70$ & $17.87 \pm 3.85$ & $48.41 \pm 2.85$ \\
\cline { 2 - 6 } & $\begin{array}{l}\text { non-Bt Providence } \\
\text { Bicolor }\end{array}$ & $3.35 \pm 0.58$ & $6.97 \pm 0.63$ & $12.95 \pm 0.86$ & $12.23 \pm 0.83$ \\
\hline North Carolina & $\begin{array}{l}\text { non-Bt Sweet G90 } \\
\text { Hybrid }\end{array}$ & $2.90 \pm 0.60$ & $9.08 \pm 0.62$ & $10.75 \pm 0.93$ & $12.76 \pm 1.16$ \\
\cline { 2 - 6 } & Seedway Bt 1576 & $5.48 \pm 0.73$ & $12.15 \pm 0.63$ & $14.79 \pm 0.69$ & $14.88 \pm 0.48$ \\
\hline Texas & $\begin{array}{l}\text { Sh2 SS2742 F1 NAT } \\
\text { III Bicolor }\end{array}$ & $7.74 \pm 1.03$ & $8.17 \pm 0.79$ & $12.95 \pm 1.19$ & $12.32 \pm 1.23$ \\
\cline { 2 - 6 } & $\begin{array}{l}\text { Silver Queen TRTD F1 } \\
\text { (su) }\end{array}$ & $6.06 \pm 1.05$ & & & \\
\hline
\end{tabular}

Table 4. Mean protein values for each region, variety, and tissue type. Mean percentages (by dry mass) are shown \pm 1 SE. 


\begin{tabular}{|l|l|l|l|l|l|}
\hline Region & Variety & \multicolumn{2}{l|}{$\%$ digestible carbohydrates } & tip kernel & base kernel \\
\cline { 3 - 6 } & & husk & $32.31 \pm 1.38$ & $36.79 \pm 1.60$ & $38.66 \pm 1.57$ \\
\hline Minnesota & $\begin{array}{l}\text { Bt Syngenta/ } \\
\text { NK-3122A-EZ (field } \\
\text { corn) }\end{array}$ & $37.55 \pm 0.88$ & $37.31 \pm 2.30$ & $35.80 \pm 1.77$ & $34.83 \pm 1.37$ \\
\cline { 2 - 6 } & $\begin{array}{l}\text { non-Bt Providence } \\
\text { Bicolor }\end{array}$ & $37.30 \pm 0.82$ & $35.28 \pm 1.17$ & $36.13 \pm 0.91$ & $39.47 \pm 1.18$ \\
\hline North Carolina & $\begin{array}{l}\text { non-Bt Sweet G90 } \\
\text { Hybrid }\end{array}$ & $35.79 \pm 0.81$ & $34.91 \pm 0.76$ & $35.73 \pm 1.35$ & $37.29 \pm 1.13$ \\
\cline { 2 - 6 } & Seedway Bt 1576 & $35.75 \pm 0.58$ & $33.40 \pm 1.10$ & $34.85 \pm 1.01$ & $39.14 \pm 1.22$ \\
\hline Texas & $\begin{array}{l}\text { Sh2 SS2742 F1 NAT } \\
\text { III Bicolor }\end{array}$ & $35.55 \pm 0.87$ & $33.42 \pm 2.33$ & $35.16 \pm 1.16$ & $33.93 \pm 1.03$ \\
\cline { 2 - 6 } & $\begin{array}{l}\text { Silver Queen TRTD F1 } \\
\text { (su) }\end{array}$ & $34.63 \pm 1.13$ & & & \\
\hline
\end{tabular}

Table 5. Mean carbohydrate values for each region, variety, and tissue type. Mean percentages (by dry mass) are shown \pm 1 SE.

\section{Discussion}

By combining well-established colorimetric assays with effective plant-specific extraction protocols, the assays demonstrated here provide a reasonable and accurate method for measuring plant soluble protein and digestible carbohydrate content. Our results using corn as an exemplar illustrates how these protocols can be used to obtain precise measurements across different biologically-relevant spatial scales. For example, we were able to detect differences in plant soluble protein and digestible carbohydrate content between geographic regions, varieties (or genotypes), tissue types, and even spatially segregated tissues. Both assays can be done using common laboratory equipment and reagents, requiring only basic laboratory skills, and can analyze a relatively large number of samples (50-75) within a short timeframe.

Although relatively easy to perform, some steps are more critical than others, and if done incorrectly can limit the accuracy of the results. For example, it is imperative that plant materials are handled properly during the sampling stage. Even dissected plant tissue will remain metabolically active until exposed to a lethal temperature, and during this period plant macronutrient content can change. As a result, long time periods between plant sampling and freezing (either by liquid $\mathrm{N}$ or freezer storage) can increase the likelihood that sample plant macronutrient content may not reflect the content that was present at the time of sampling.

Steps 2.3.3-2.3.5 in the protein protocol are particularly important for a successful outcome, as these steps deal with the precipitated proteins. Care must be taken to avoid losing any of the protein pellet when vacuuming the supernatant TCA from the microcentrifuge tubes, because doing so will result in an underestimation of protein content. It is also important when washing the protein pellet with acetone to do so very quickly. Acetone can degrade the pellet if left in contact for more than several seconds. We suggest limiting contact between acetone and the pellet to less than 5 seconds. Finally, when drying the pellet, it is important to take care to only allow enough time for the acetone to evaporate. If the pellet is left to dry for too long, it becomes very difficult to resuspend in $\mathrm{NaOH}$. We suggest drying the pellet for 30 minutes, and then checking for the presence of acetone, either by visually observing liquid in the tube or by carefully detecting the smell of acetone fumes. Continue checking the pellet every 10-15 minutes until the acetone has evaporated.

As outlined in Bradford $1976^{16}$, the quantification steps using Coomassie brilliant blue G-250 dye allow for high sensitivity, with a standard deviation of only $5 \mu \mathrm{g}$ protein/mL, high protein-dye complex stability, and limited interference by non-protein compounds. This assay has a detection range between $1-20 \mu \mathrm{g}$ total proteins per microplate well (low-concentration assay) or a maximum of $25 \mu \mathrm{g} / \mathrm{mL}$; however, any concentration that exceeds the highest standard should be diluted and re-analyzed for the most accurate results (the protocol produces an excess of solution in case such dilutions and re-analysis is necessary). There is a bias for the dye to preferentially bind to basic amino acids, such as arginine, and aromatic amino acid residues; however, the Bradford assay remains the most accurate and easy to use method for total protein quantification in mixed samples.

The digestible carbohydrate assay is a fast, cost-effective, and simple method for quantifying plant saccharides while excluding structural carbohydrates (such as cellulose), which are indigestible by most herbivores. The most problematic steps in the carbohydrate assays are steps 3.2.1 and 3.3.2-3.3.4. Here, it is critical to keep tubes upright and to tighten the screwcaps well when boiling, as the introduction of any water will dilute samples and affect accurate quantification. Also, care must be taken when working with phenol and concentrated sulfuric acid, as both are highly corrosive. It should be noted that we advocate recording sample absorbance at $490 \mathrm{~nm}$, which is the maximum absorbance for hexoses, but not other sugars, such as pentoses and uronic acids which have a maximum absorbance at $480 \mathrm{~nm}^{20,21}$. For sugar mixtures in plant samples, $490 \mathrm{~nm}$ provides an appropriate wavelength for quantifying overall carbohydrate content ${ }^{22,23,24}$, but for a more detailed analysis of different sugars see ${ }^{20,21}$. It should also be noted that Masuko et al. ${ }^{23}$ provides a streamlined microplate method for phenol-sulfuric acid carbohydrate analysis.

Another notable method for estimating plant nutrient content ${ }^{25,26,27}$ is near-infrared spectroscopy (NIRS). NIRS technology is widely used in agricultural and food production. This alternative technique is noninvasive, nondestructive, takes a fraction of the time involved in any wet chemistry method, and can be applied at different scales from a landscape down to an individual piece of plant tissue. This technique measures nutrients indirectly and relies on accurate wet chemistry measurements of the plant chemical of interest for calibration. The methods described herein will therefore have a critical place in the future of plant nutrient analysis, ensuring that calibration is based on soluble and digestible macronutrient quantification and not biased by non-nutritive elemental surrogates. 
The methods presented for measuring plant soluble protein and digestible carbohydrate content have significant implications for the environmental and biological sciences. Despite a wealth of information on the elemental composition of plant tissues, information on plant macronutrient content is severely lacking. Given the limitations that exist in correlating elemental measures with macronutrient content and acknowledging the strong relationship between plant nutritional content and higher order ecological processes, obtaining this kind of data is essential for advancing the fields of plant physiology, nutritional ecology, plant-herbivore interactions, food-web dynamics ${ }^{11,28,29,30}$. It is our hope that providing a clear and approachable methodology for measuring plant soluble protein and digestible carbohydrate content will encourage researchers to collect and incorporate this kind of data into future research.

\section{Disclosures}

The authors have nothing to disclose.

\section{Acknowledgements}

Thanks to all of our collaborators who have assisted with sweet corn field collections, including Dominic Reisig and Dan Mott at North Carolina State University, and Pat Porter at Texas A\& M University in Lubbock, TX. Thanks to Fiona Clissold for helping to optimize the protocols and for providing edits to this manuscript. This work was supported in part by the Texas A\& M C. Everette Salyer Fellowship (Department of Entomology) and the Biotechnology Risk Assessment Grant Program competitive grant no. 2015-33522-24099 from the U.S. Department of Agriculture (awarded to GAS and STB).

\section{References}

1. Simpson, S.J., Raubenheimer, D. The Nature of Nutrition: A Unifying Framework from Animal Adapation to Human Obesity. Princeton University Press: Princeton, NJ. (2012).

2. Behmer, S.T. Insect herbivore nutrient regulation. Annual Review of Entomology. 54, 165 - 187 (2009).

3. Epstein, E. Mineral nutrition of plants: mechanisms of uptake and transport. Annual Review of Plant Physiology. 7 (1), 1 - 24 (1956).

4. Chapin III, F.S. The mineral nutrition of wild plants. Annual Review of Ecology, Evolution, and Systematics. 11 (1), 233 - 260 (1980).

5. Marschner, H. Marschner's Mineral Nutrition of Higher Plants. Academic press: London, UK. (1956).

6. Stieger, P.A., Feller, U. Senescence and protein remobilization in leaves of maturing wheat plants grown on waterlogged soil. Plant and Soil. 166, 173 - 179 (1994).

7. Li, R., Volenec, J.J., Joern, B.C., Cunningham, S. M. Seasonal changes in nonstructural carbohydrates, protein, and macronutrients in roots of alfalfa, red clover, sweetclover, and birdsfoot trefoil. Crop Science. 36, 617 - 623 (1996).

8. Sánchez, E., Rivero, R. M., Ruiz, J. M., Romero, L. Changes in biomass, enzymatic activity and protein concentration in roots and leaves of green bean plants (Phaseolus vulgaris L. cv. Strike) under high NH4NO3 application rates. Scientia Horticulturae. 99,237 - 248 (2004).

9. Lenhart, P.A., Eubanks, M.D., Behmer, S.T. Water stress in grasslands: Dynamic responses of plants and insect herbivores. Oikos. 124, 381 390 (2015)

10. Machado, A.R., Arce, C.C. M., Ferrieri, A.P., Baldwin, I.T., Erb, M. Jasmonate-dependent depletion of soluble sugars compromises plant resistance to Manduca sexta. New Phytologist. 207, 91 - 105 (2015).

11. Deans, C.A., Behmer, S.T., Fiene, J., Sword, G.A. Spatio-temporal, genotypic, and environmental effects of plant soluble protein and digestible carbohydrate content: implications for insect herbivores with cotton as an exemplar. Journal of Chemical Ecology. 42 (11), 1151 $1163(2016)$

12. Boisen, S., Bech-Andersen, S., Eggum, B.O. A critical view of the conversion factor 6.25 from total nitrogen to protein. Acta Agriculturae Scandinavica. 37, $299-304$ (1987).

13. Ezeagu, I.E., Petzke, J.K., Metges, C.C., Akinsoyinu, A.O., Ologhobo, A.D. Seed protein contents and nitrogen-to-protein conversion factors for some uncultivated tropical plant seeds. Food Chemistry. 78, $105-109$ (2002)

14. Izhaki, I. Influence of nonprotein nitrogen on estimation of protein from total nitrogen in fleshy fruits. Journal of Chemical Ecology. 19, 2605 $2615(1993)$.

15. Mossé, J. Nitrogen to protein conversion factor for ten cereals and six legume or oilseeds. A reappraisal of its definition and determination. Variation according to species and seed protein content. Journal of Agricultural and Food Chemistry. 38, 18 - 24 (1990).

16. Bradford, M. M. A rapid and sensitive method for the quantitation of microgram quantities of protein utilizing the principle of protein-dye binding. Analytical Biochemistry. 72 (1-2), 248 - 254 (1976)

17. Jones, C.G., Hare, J.D., Compton, S.J. Measuring plant protein with the Bradford assay. Journal of Chemical Ecology. 15 (3), 979 - 992. (1989).

18. Dubois, M., Gilles, K.A., Hamilton, J.K., Rebers, P.A., Smith, F. Colormetric method for determination of sugars and related substances. Analytical Biochemistry. 28, 350 - 358 (1956).

19. Clissold, F.J., Sanson, G.D., Read, J. The paradoxical effects of nutrient ratios and supply rates on an outbreaking insect herbivore, the Australian plague locust. Journal of Animal Ecology. 75, 1000-1013 (2006)

20. Smith, D., Paulsen, G. M., Raguse, C.A. Extraction of total available carbohydrates from grass and legume tissue. Plant Physiology. 39 (6), $960-962(1964)$

21. Cui, S.W. Food carbohydrates: Chemistry, physical properties, and applications. CRC Press: Boca Raton, FL, USA. (2005)

22. Chow, P.S., Landhäusser, S. M. A method for routine measurements of total sugar and starch content in woody plant tissues. Tree Physiology. 24 (10), $1129-1136$ (2004)

23. Masuko, T., Minami, A., Iwasaki, N., Majima, T., Nishimura, S.I., Lee, Y.C. Carbohydrate analysis by a phenol-sulfuric acid method in microplate format. Analytical Biochemistry. 339 (1), 69 - 72 (2005).

24. Foley, W.J., Mcllwee, A., Lawler, I., Aragones, L., Woolnough, A.P., Berding, N. Ecological applications of near infrared reflectance spectroscopy- a tool for rapid, cost-effective prediction of the composition of plant and animal tissues and aspects of animal performance. Oecologia. 116 (3), 292 - 305 (1998). 
25. Kokaly, R.F. Investigating a physical basis for spectroscopic estimates of leaf nitrogen concentration. Remote Sensing of Environment. 75 (2), 153 - 161. (2001).

26. Schulz, H., Baranska, M. Identification and quantification of valuable plant substances by IR and Raman spectroscopy. Vibrational Spectroscopy. 43 (1), $13-25$ (2007).

27. Cozzolino, D., Morón, A. The potential of near-infrared reflectance spectroscopy to analyse soil chemical and physical characteristics. The Journal of Agricultural Science. 140, 65 - 71 (2003).

28. Simpson, S.J., Sword, G.A., Lorch, P.D., Couzin, I.D. Cannibal crickets on a forced march for protein and salt. Proceedings of the National Academy of Sciences of the United States of America. 103 (11), 4152-4156 (2006).

29. Lihoreau, M., Buhl, J., Sword, G.A., Raubenheimer, D., Simpson, S.J. Nutritional ecology beyond the individual: a conceptual framework for integrating nutrition and social interactions. Ecology Letters. 18 (3), 273-286 (2015).

30. Deans, C.A., Behmer, S.T., Tessnow, A., Tamez-Guerra, P., Pusztai-Carey, M., Sword, G.A. Nutrition affects insect susceptibility to Bt Scientific Reports. 7, 39705 (2017). 